\title{
RACE, CULTURE AND SURVIVAL IN THE GREATER CARIBBEAN: A LESSON FOR US ALL
}

\author{
(C) Quince Duncan
}

Universidad Nacional de Costa Rica (emeritus)

E-mail - qduncan@yahoo.co

\section{DEFINITION OF THE TERM: CULTURAL AREA}

There is a vast area, extending from New Orleans in the North, through Veracruz on the Atlantic coast of Mexico, the Caribbean coast of Central America, including Belize, Guatemala, Honduras, Nicaragua, Costa Rica and most of the Isthmus of Panama, all of the Caribbean Islands, and the Atlantic coast of the northern part of South America including Colombia, Venezuela and ending in the Guyanas. It is termed Greater Caribbean.

One of the most outstanding characteristics of the Greater Caribbean is its cultural diversity, among which one can perceive the decisive presence of the African culture. The Greater Caribbean is definitely a cultural entity with a very unique identity.

People living in this area are more aware of their uniqueness, as compared to the neighboring cultural communities. But only a minority has an encompassing awareness of the magnitude and dimension of their culture, a rather peculiar cultural formation that sometimes doesn't seem to be self-conscious. I remember being invited in the United States to enjoy a traditional New Orleans that turned out to be completely equivalent to the soup my Jamaican grandmother used to prepare for me in Puerto Limon, Costa Rica, a matter that turned out to be of concern to me, when she died. As a six-year old boy, I raised the following point with my Mom: "Now, who's going to cook my soup for me?"

But even if the people of Surinam or Venezuela are unaware of the common cultural traits they share with the people of New Orleans, they would definitely like the food and enjoy jazz. And while one might need a bit of cultural introduction/initiation and a few pounds of persuasion to get people from North Carolina or Wisconsin to understand that you have to move your hips to dance salsa or mambo, people from Miami can have a big party and feel very much at home in any Caribbean carnivals. They need no introduction. 


\section{DESCRIPTION OF THE GREATER CARIBBEAN}

The Greater Caribbean is a vast geographical and cultural block with a very wide definition. It has no political identity at the moment, nor can one perceive such unity in the near future. Geographically, it crosses over to the Pacific Coast via Panama and intrudes into the Gulf of Mexico via the U.S. Its culture is certainly distinguishable in the continent's interior zones, and very different from the Pacific coast regions.

It is well known for its strong winds - hurricanes, cyclones, tropical depressions. In addition, the Greater Caribbean is associated with plaque phenomenon, faults, and volcanoes that produce frequent headlines in the media.

It is also an area of unsolved mysteries, that include the many facts and legends associated with the Bermuda Triangle

But, let me insist on the following: What strikes the eye of any outsider at first sight, is its diversity and its racial and ethnical diversity.

It is a fact that a large number of cultural formations call the Greater Caribbean their homeland. The following outline will help us understand the complexity of this cultural reality:

Reconstructed Amerindian cultures

African reconstructed cultures

Afro-Amerindian mestizos

Afro-European mestizos

Euro-Amerindian mestizos

European reconstructed cultures

Multiethnic societies

Panethnic cultures

\section{RECONSTRUCTED AMERINDIAN CULTURES}

As we all know, from the fifteenth century on, there has been a systematic and very aggressive expansion of the Western culture, first by means of direct military conquest and colonization, and later by 
more subtle economical, political and, cultural influence. In this process of conquest, the majority of the native cultures of the Americas lost their cultural structures and/or lives. In the case of the U.S. and the Insular Caribbean, native people were literally wiped out and very few survived. This is a case of overt genocide and ethnocide, by means of wars of extermination, illnesses introduced by the Europeans, forced labor, drastic decrease of the nutritional level, caused by the destruction of their productive systems and the appropriation of vital goods by the invading nations.

In the case of Central America, some Amerindian populations survived, did succeed in retaining some elements of their original culture, and rebuilt them. The Maya of Guatemala and the Cabecar of the Panama-Costa Rica frontier areas are good illustrations of this. These people continue to speak their own language, which is being taught in local schools.

\section{AFRICAN RECONSTRUCTED CULTURES}

One issue that has yet to be the subject of in-depth studies is the maroon phenomenon. During the colonization period, many African slaves escaped from captivity and managed to establish themselves in the mountains or jungle areas. They formed palenques and kilombos (Portuguese quilombos) in those territories, and even managed to survive as independent or autonomous political entities for many years. In Mexico, Yanga forced the Spanish Crown to grant freedom to his runaway slaves in an autonomous region. In Colombia, black groups were able to force the rulers to negotiate special status for themselves. In Jamaica, the maroon areas kept their status as an autonomous territory until the country gained independence after the Second World War.

It is amazing how these groups have been able to preserve and develop their cultural inheritance; and distances from Africa both in time and space not withstanding, they share astonishing similarities with their contemporary African counterparts.

Of course the most accomplished example of reconstructed cultures is Haiti, a nation that liberated itself from slavery and achieved independence, as the first free Latin American nation. And in spite of internal class conflicts, European and U.S. invasions, blockades, and other forms of political and economic aggression, Haiti has survived as a people nation, preserving and developing many elements and systems characteristic of the African continent. 


\section{AFRO-AMERINDIAN MESTIZOS}

Another interesting case is that of the Afro-Amerindian mestizos. These are new cultural formations resulting form the miscegenation and association between the African and the Native populations. We are not talking about coexistence. The fusion in this case is complete. I guess the best examples can be taken from Central America: Misquitos and Garífunas.

In the case of the Misquitos, the nation was formed as a result of the blending of local Amerindian tribes and African runaway and shipwrecked slaves on the Nicaraguan coast. There is no doubt that the Africans were assimilated into the Misquito culture. The Africans adopted their language and customs, and their children identified themselves as Misquitos.

The Garifunas are somewhat the opposite. They are the descendants of runaway slaves that mixed with the rebellious Carib Indians. They trace their origins to Saint Vincent, a Caribbean island, where, due to their never ceasing fight for freedom and unwillingness to recognize the sovereignty of the colonial powers, the British government expelled some of them from its territories. The British took them to the island of Roatán in Honduras where the Garifunas adapted to the conditions of local life and succeeded in working out agreements with the Spanish government to colonize parts of Honduras. Later on they also moved to Belize, Guatemala, and Nicaragua. The Garifunas is a brilliant example of cultural survival. They have been able to develop their language, culture, and identity as a group.

\section{AFRO-EUROPEAN MESTIZOS}

A large number of Caribbean people are Afro-European mestizos, resulting from the mixing of Europeans with Africans. This is very obvious on the islands. As a general rule, one can state that the Caribbean culture is predominantly a mixture of Afro European, namely African and Spanish, English, French, Dutch, Portuguese.

As a result, the new cultural formations are rich and new cultural hybrid forms, in which the origins of various elements are clearly recognizable. This includes for example, the presence of European languages along with African systems of belief. But at the same time, the culture of Afro European mestizos contains abundant original expressions, for example in the field of music. This phenomenon is clearly appreciated in countries like Cuba, the Dominican Republic, Puerto Rico, Panama, Martinique, Curaçao, and Jamaica. 


\section{EURO-AMERINDIAN MESTIZOS}

A large number of the people of the Caribbean are the result of the mixture between the immigrant Europeans and local native indigenous populations. In general, the Euro Amerindian population adopted the dominant European culture, but at the same time, did keep some elements of the native cultures. This segment of the population, identify themselves as "white" and many of them suffer from what I have termed severe Europhilia, or a systematic negation of their own values and a mythical exaltation of the European culture of which they consider themselves heirs.

Good examples of this can also be found in Costa Rican and Colombian coast, although it must be stated that this identity crisis is shared with nationals belonging to extra Caribbean cultural groups.

\section{EUROPEAN RECONSTRUCTED CULTURES}

In some instances, for example, in some Dutch and French colonies, during the colonial times, a white elite managed to preserve and reconstruct the culture of their country of origin on the American continent. Some managed to secure strongholds and have survived in their own islands up to the present. But in other cases, issues and events related to the wars of independence and the conflicts between the ruling and imperial nations of the time caused migrations of these dominant white sectors from the colonies to new places. Let's mention the case of the French speaking "Creoles" that settled in New Orleans, in turn reconstructing cultural forms characteristic of the white elite of the Caribbean in that new context.

\section{MULTIETHNIC SOCIETIES}

In other parts of the Greater Caribbean one can find an impressive diversity of cultural groups, including people of Oriental origins. These include people from India in Trinidad Tobago or China in Port Limon, Costa Rica. Other examples include Guyana and Belize. This diversity includes the coexistence of groups of European origins, African, Amerindian, Eastern as well as complex combinations of them all.

\section{PANETHNIC CULTURES}

Our final example is Veracruz, Mexico. And we have chosen the term Panethnic to describe cultural formations in which people of different ethnic backgrounds have mixed to such degree that they have lost all notions of their roots. The original cultural forms are no longer recognizable at first sight. Very few elements are clearly "European," 
"indigenous," "African" or "Eastern". Veracruzan culture is a hybrid totality, both racially and culturally.

\section{CARIBBEAN: UNIQUE AND ONE}

We now come to the core of the matter. The good news is that beyond this rich diversity, Caribbean people share a culture that is one and unique.

African culture on the one hand is a unifying factor. European languages is another factor, although less universal than African culture. Taken from a racial and ethnical point of view, the totality of the population can be considered racially and/or culturally mestizo.

But what is so impressive about this diversity, is the Caribbean people's ability to live together without any major racial conflict, and to develop cultural landmarks to which all Caribbean people can easily relate.

The culinary arts, the visual arts, the Creoles and Patois, the myths, the legends, the architecture, the carnivals, the musical instruments. Oral traditions, food, sports, all blend together in the Greater Caribbean. Music gives us a good number of examples. Just name it. Whether it is jazz, it is reggae, it is calypso, it is socca, it is guaracha, it is salsa, it is mambo, it is merengue, it is cumbia. Any person originating from the Greater Caribbean recognizes, immediately identifies with several or all of these forms of Caribbean music, and tends to manifest preference for them in relation to other musical forms.

Another common and fundamental feature that marks the Caribbean culture, no matter how paradoxical it may sound, is this ability to live in harmony with nature. The zone has been devastated by colonial powers and transnational corporations carried out in the past and persist in carrying out a totally irrational exploitation of the natural resources of the area. The Greater Caribbean has contributed vast amount of raw material, produce, and products for the European market, and through slavery and servitude, has helped create the necessary leisure time that enabled European societies to dedicate themselves to scientific investigation.

As a result of this process, the Caribbean has suffered the effects of deforestation, single production, and overexploitation. Whether by the British on the Nicaraguan coast, or the Spanish in the Dominican Republic, the result is the same. 
In spite of the above-described reality, when one compares the continental Caribbean Area to the Central and Pacific zones, one perceives an inclination to have a more harmonious relationship with nature.

Another interesting idea has been already mentioned, but I think it is important to underline. The levels of tolerance, which traditionally, have been higher in the Greater Caribbean than in other areas of our Continent. In fact, this diversity factor forced coexistence on the numerous groups of natives, reconstructed cultures, new cultural formations and mestizos creating a microcosm, and an outstanding example of tolerance.

I don't deny the confrontations that we have gone through, for example, in Nicaragua, Guyana, and Trinidad and Tobago. It is simply a question of comparing, of measuring, the levels of conflict with historical perspective in order to realize that the culture of the Caribbean is more inclined towards religious and ethnic and racial tolerance than towards violent confrontation.

\section{ETHICS FOR SURVIVAL}

The history of the Greater Caribbean is one of political conflict. Slavery, servitude, racism political domination all conspire against the region and one would expect to find a pandemonium of racial and ethnical confrontations.

I think that comparative cultural studies should be studied by all of us. And when we take a close look at the Caribbean, I daresay, we have a lot to learn about tolerance, living in harmony with nature, building a non racial society, based on the universal law of survival in plenitude. Survival of the self as an entity capable of relating to the other without having to either feel threatened or to threat. Survival in plenitude for oneself means is not having to feel tense or intellectually superior or inferior in the presence of someone physically or culturally different. Survival in plenitude for oneself is being able to be at ease in the presence of diversity. But survival in plenitude also means having the possibility to create a better world for children. A world in which they can be whatever they choose to be, and still not have to go through the traumas that emphasize, not to appreciate it but to rather to undermine a part of it and to negate the contribution of some to the common lore. Survival in plenitude also means to be able to appreciate the values of the other, to understand the other's point of view even when it might be far away from our own. Survival in 
plenitude means to be able to identify oneself far beyond County, Tribe, State, Country -as a member of the Human Race.

People of the Caribbean have learned and are learning many of these lessons in the field of Survival, and have been able to liberate themselves in daily life from the slavery of racial and ethnical hate and suspicion, making it possible to love the other, even when He or She might be so distinctly different. For beyond the diversity of the Human Being, and our history of stupidity and bigotry, there is this dignified presence of a Consciousness that is aware of being Conscious.

A Being entitled to be free.

And that is precious.

A Being created for love.

And that is beautiful.

A Being created for transcendence.

And that is enduring.

And that is survival in plenitude.

And that is what really, really matters. 